\title{
NEGATIVE ATTITUDES IN SIDNEY SHELDON'S NOVEL THE BEST LAID PLANS
}

\author{
Luna Rezki Dafnari, Devi Pratiwy \\ English Department, Faculty of Literature \\ Universitas Islam Sumatera Utara (UISU), Medan \\ e-mail: lunarezkidafnari@gmail.com
}

\begin{abstract}
This research analyses the negative attitudes of the protagonist in The Best Laid Plans written by an American novelist, Sidney Sheldon. The novel tells the revenge of the selfish and ambitious protagonist Leslie Stewart who has been so obsessed with destroying Oliver's reputation for betraying him. Leslie is the most fascinating figure in the whole course of the story between his selfish and ambitious attitude and his madness. She feels that she has been neglected and cast away and this hardens his heart, until she does not care about the feelings of others. This phenomena is compatible with a theory of selfish in which it is stated that When talking, he does not care about the feelings of others. If there is a division of something he is selfish. He never thought that his actions caused many people to be harmed (Poniman, 2007). This research adopts qualitative method supported by relevant theories, one of which is proposed by Creswell (2009). The result reveals that there are two dominant attitudes emerging from the analysis, those are selfish and ambitious.
\end{abstract}

Keyword: Protagonist, Negative attitude, The Best Laid Plans.

\section{Introduction}

The Best Laid Plans is a novel written by Sidney Sheldon in 1997. It tells the explosive story of the beautiful and ambitious Leslie Stewart, who learns that for some men power is the greatest aphrodisiac; and of Oliver Russell, the handsome governor of a small southern state, who finds out why hell has no fury like a woman scorned.

Based on the story of the novel, it shows dominant by the negative attitude of the character, Leslie. Leslie Stewart learns that for some men, power is the greatest aphrodisiac. First she works in an advertising firm, then married to a large scale business man. She bought many newspapers and sees TV channels to take grudge on Oliver Stewart who first promised to marry her but later married daughter of senator Todd Davis so that he could become governor one day.

Attitude is a mental habit that gives guidance on how a person sees the world around and the reactions one takes in response. An attitude is not a permanent object in human life. It could be learned, changed or abolished. Attitude is mainly the result of social learning in a certain environment. Attitude comes from sound thought. Theoretically there are three steps developing an attitude, affect, behavior and cognition. Affect is connected with desire as this is a psychological response that exposes one's preference for a whole. This is called the basic development of an attitude. In the second development there is a verbal indication of the intention of an individual. While in the 
third a cognitive evaluation of the entity to form an attitude is formed. So there is no auto-formed attitude as it develops gradually and by the outward influences (Ernawati, 2012). There are some attitudes which are regarded negative proposed by Hayati (2019). The first is anger. A person with a negative mindset is often found to be angry most of the time. Sometimes there might not be any kind of specific reason behind their anger. Anger is the root cause of self-destruction. While some amount of anger is good, extreme cases of anger only lead to destruction. The second is doubt. A person can question himself but he or she should never doubt themselves. Unfortunately, if you have a negative mindset, then you will often doubt yourself. Self-doubt will lead to no progress and will often lead to low confidence. And the last is frustration. A negative person is a frustrated person. As said earlier, attitude defines the person and that is why if you are frustrated that will show on your face and you will be facing some serious difficulties. Frustration will not help you build your career. It is an irritant and will keep preventing you from taking any positive step forward.

The objectives of this research are to reveal and describe negative attitudes of the protagonist which concern only with his selfishness and ambition implied in the novel. Thus, the focus of this study goes to protagonist attitude, in which two significant elements emerge. In a broad clarification, attitude is classified into three: positive attitude, negative attitude and neutral. And the focus of the study goes to the negative attitude of the protagonist.

The significance of this research is hoped that this research may inspire others to introspect themselves whether they have such negative attitude consciously or unconsciously contribute a reference in literature studies.

\section{Literature Review}

Attitude is formatted by the exposition of affect, behavior and cognition, which later creates a personality specificity. Attitude and behavior are only linked on the basis of attitude specificity, attitude parallelism, social restrictions and personality (Kenneth, 1998). Schiffman \& Kanuk (2004) suggest that attitudes are constructed around three components. They are (1) A cognitive component (beliefs), (2) An affective component (feelings), and (3) A conative component (behavior).

Hayati (2019) stated that a negative attitude is something that every person should avoid. Generally, people who have negative attitude ignore the good things in life and only think about whether they will fail. They often find a way out of tough situations by running away from it. They often compare themselves with other persons and find the bad in them only. In short, he is exactly the opposite of the one with a positive mindset. There are certain bad effects that a person with a negative mindset has to face. A bad or negative attitude shows a bias toward negativism, either with regard to some object, work, or to life general ( Lopper : 1992). Negative attitude comes from a wrong belief of life and if this is kept it will guide a person concerned into a firing soul which will surely kill the person. One of the significant consequences of negative attitude is stress that will be easy turned into depression and anxiety. Negative attitude, whatever the reason is, must not be preserved and has to be erased from the mind (Ernawati : 2012).

Selfish is someone who only thinks of himself. He doesn't care about the fate of others. Emotional intelligence is low. He is not liked by many people. When talking, he doesn't care about the feelings of others. If there is a division of something he is selfish. He never thought that his actions caused many people to be harmed (Poniman:2007). As 
noted by Crocker et al. (2017), selfish behavior can lead to greater gains in the short term. In the long run, however, the relation between selfishness and material benefits could be more complex and there are clear bases for competing hypotheses. On the one hand, even over the longer term, we might expect appositive relationship between selfishness and income, because those who value their self-interest will tend to pursue jobs that emphasize greater rewards to themselves.

Ambition is motivational formation and represents aspiration of a person to be a significant and a recognized personality to others for real achievements, important both for person and for other people (Barsukova, 2014).

Ambition involves perseverance and generalization where we don't expect ambitions to stop there is once a certain level of achievement is reached. Ambition is also generally already taken to reflect the struggle for position and wealth, and not to show an effort for public welfare moderate and social-emotional acceptance. In short, ambition is about achieving rather than achieving. Attitude of ambition is not something bad but ambition can be an encouragement in themselves to get the goal to be pursued. Ambitious can be positive if not excessive. In the positive, ambitious people make themselves in control of their lives without depending on circumstances and others. They have clear and strong mental goals to achieve their ideal achievements in earnest. In this novel, ambitious leads to a negative attitude for the protagonist show excessive characteristics.

\section{Research Method}

The researcher chooses a qualitative descriptive as the design of the analyzing the data. According to Creswell (2009: 3) research design is plans and the procedures for research to detailed methods of data collection and analysis. Qualitative research is a means for exploring and understanding the meaning individuals or groups to a social or human problem. The design of this research is to understand and to describe the negative attitude which is implied in the novel. According to the approach of sociology of literature, literary works are seen from their relationship with reality, the extent to which literary works reflect reality. The reality here is quite broad in meaning, that is, everything that is outside the literary work and which is referred to by the literary work itself. (Hidayati, 2019).

The data collection is fulfilled by conducting some steps, namely reading "The Best Laid Plans" novel repeatedly, understanding the content of the novel, finding out the data related to research problems, and writing down the significance notes in the novel "The Best Laid Plans.

The data is then analyzed through some steps as well. They are identifying data, categorizing and classifying all data in the novel, describing and interpreting data, organizing the whole data, and making conclusion based on the analyzed data.

\section{Discussion}

\subsection{Protagonist's Negative Attitude}

The protagonist has two prominent types of attitude emerging from the study are selfish and ambitious. These two types, based on some theories presented before are categorized negative in the sense that they are destructive and there are not much expected from selfish and ambitious. It already stated that selfish is associated with devilish qualities and surely to be strictly avoided. 


\subsubsection{Selfish}

The protagonist, Leslie Stewart, in Sidney Sheldon's The Best Laid Plans, in his action always demonstrate an attitude of selfish. Consciously or unconsciously Stewart's downfall is mainly caused by his uncontrollable of selfish.

He had been a dear, sweet man, and she had used him because she wanted him to help her get revenge against Oliver (Sheldon, 1997: 74)

Henry's death had affected Leslie more than she had expected. He left his entire estate to Leslie. And somehow, in Leslie's mind, Henry's death became another reason to destroy Oliver. She does not feel sad over the loss of her husband, because the second step of his plan to destroy Oliver was successful.

All Henry's wealth was given to Leslie and the next plan would begin. Since she was holding her husband's company, she bought another newspaper company and wanted to get information about newspapers to sell across the United States.

Starting Monday, we're cutting the price of the Sun from thirty-five cents

to twenty cents. We're cutting our advertising rates by thirty percent.

Next week we are starting a giveaway contest where our readers can we

free trips all over the wold. We'll begin publicizing the contest immediately ( Sheldon, 1997: 77)

Leslie is the most selfish woman, in order to achieve her desire she spends a lot of money to be able to compete with other newspaper companies, she lowers the selling price and makes a giveaway that costs a lot. She attracts customers to buy newspapers at his company, his main goal is to be able to make other companies out of business and go bankrupt, so she can buy the company.

However Leslie was worried. The losses were getting heavier every week. Circulation continued to dwindle, and advertisers reactions to the rate reduction had been lukewarm. The following week, the circulation stopped dropping. It took eight weeks for the Sun to begin the rise.

The reduction in the price of the newspaper and in the cost of advertising was attractive, but what made the circulation of the Sun move up was the giveaway contest. It ran for twelve week, and entrants had to compete every week. The prize were cruises to the South Seas and trips to London and Rio. As the prize were handed out and publicized with front-page photographs of the winners, the Leslie company exploded, and the enemy company went bankrupt and sold it to Leslie Stewart.

"I don't care, hire him". Later that day, Matt Baker told her, "I checked on Zoltaire. It would be too expensive to buy out his contract". "buy it". (Sheldon, 1997:185)

Leslie asks astrologers to work for her, while she is actually not interested in astrology and nobody tries her company. Leslie is a very selfish woman, whatever she does to the best of her plans. In fact, she pulled one of the smartest workers in his enemy's company and paid whatever they asked for. She attracts astrologers in the company of his enemies.

Leslie's goal was to defeat the enemy's company and buy the company, so she took very influential workers from the company.

"And there's too much fat around here. Get rid of the reporters who aren't pulling their weight." (Sheldon, 1997: 186). 
Leslie dismissed all that was disapproved and did not contribute to the maximum. She wants young reporters who are hungry. She does not think of employees who have worked for her company for a long time. Leslie is the most selfish woman to achieve her desires, she never cares about the quality of company reporting, she only needs news about Oliver Russell's

Leslie Stewart's private life was a subject of endless discussions at the Tribune. Leslie is a smart and beautiful woman but very strange, her selfishness sometimes makes her life worse, she is never calm seeing Oliver happy, she is always dissatisfied with what she gets now, her life's goal is only to destroy her ex-fiancée

"Run it, "she said. "put it out as an extra. I want it to hit the streets in an hour, and WTE can broadcast the story at the same time. "Lyle Bannister hesitated. "you don't think Matt Baker look at?" "this is not this paper, it is mine. Run it. Now."

Leslie wanted to news about the murder charge of Oliver in print, But one of this employees refused, Leslie became very selfish when his wishes were not fulfilled, she forced his employees to write about Oliver, even though the news was untrue, but Leslie did not care, because she was the owner of the newspaper, whatever she can do it, she just wants Oliver destroyed with the news.

\subsubsection{Ambitious} inflexible.

Leslie Stewart makes his life and other's difficult by being overly ambitious and

Leslie Stewart had given a lot of thought to the various ways in which she could meet Hendry Chambers. There were endless fin possibilities, but she discarded them one by one. What she had in mind had to be planned very carefully (Sheldon, 1997: 56).

Leslie wants to avenge her Oliver through a well-known mass media entrepreneur, Henry. She has specific intention with the mass media, Leslie is a very smart woman, she thinks about her plans very thoroughly.

The solution to Leslie's problem had come in two disparate item items in the Lexington Herald-Leader. And that was when the idea jelled. Leslie had spent the next two day doing research on Hendry Chambers was a fifty-five-year-old philanthropist who had inherited a tobacco fortune and had devoted most of his life to giving it away. But money that interested Leslie. It was the fact that he owned a newspaper and that he had just gotten a divorce.

Bookstores were filled with how to books for woman on how to get a man. The various pop psychologies ranged from "play hard to get" to "get them hooked in bed." Leslie followed none of that advice. She had her own method: she tasted Hendry Chambers. Not physically, but mentally. Hendry had never met anyone like her. He was of the old school that believed if a blonde was beautiful, she must be dumb. It never occurred to him that he had a always been attracted to women who were beautiful and not overly bright. Leslie was revelation to him. She was intelligent and articulate and knowledgeable about an amazing range of subject. 
Henry Chambers enjoyed Leslie's company tremendously, As they got closer, Henry proposed to Leslie and Leslie's initial steps to destroy his ex-fiancé were successful.

She had been busily expanding her empire and had acquired a chain of newspapers and television and radio stations across the United States, as well as in England, Australia, and Brazil (Sheldon, 1997: 147)

Leslie is never satisfied with what she has now, she buys almost all the mass media in the world, Leslie expands her business empire. Leslie's ambitious attitude was even higher when he heard Oliver Russell won by more than two million popular votes and most of the votes, and he was the current president. She searched all the newspapers or TV stations that I wanted to sell, she never had enough. She is turned respectable newspapers into cheap tabloids, Leslie doesn't care about his company's reputation being ugly.

Leslie has a bad reputation, people do not like working for Leslie Stewart. But she has many ways so that employees do not resign, she promised to double his salary and make a leader in one of his companies. Leslie is a beautiful woman, young and smart, but behind it all she is a very ambitious woman, she can do anything for her desire to be achieved.

They were in a fierce embrace, and he took her hand and led her into the bedroom. They began undressing each other (Sheldon, 1997: 181)

The inaugural celebrations, the parades, and the swearing-in ceremonies were over, and Oliver officially becomes president. Since Leslie controlled almost all newspapers and TV stations, she began to plan his revenge on Oliver, the more people got to know Oliver, the easier Leslie made news that destroyed the good name of Oliver.

In the news that was made president accused of campaign fraud. Oliver investigated the origin of the news, and looked for the owner of the newspaper who made the news about it. After learning that the owner of the newspaper was Leslie Stewart, he realized that Leslie wanted revenge on him, so Oliver invited Leslie to dinner and talk about the news that was alleged to him. They drifted past, and went into the bedroom. Oliver thought Leslie still loved him, even though it was just hate.

Leslie uses the situation to be able to do the next plan. A woman who very ambitious, she is willing to give her body to a man she really hated for a goals to be achieved. She reassures Oliver that she seems to still love Oliver, unknowingly Oliver is trapped by the situation that night, Oliver thinks that Leslie still loves him, and in Oliver's mind, Leslie will stop making news about him, because their relationship has improved.

But on the contrary, Oliver mistakenly interpreted, Leslie's passion flared because of hatred, not because of love, so with that incident Leslie was more free to make news about the affair that occurred between the two of them.

"He's not fit to be in that office, and I'm going to do everything I can to

make sure that he's defeated in the next election" (Sheldon, 1997: 192)

Leslie tries to make Oliver haunted by the news that makes his reputation increasingly ruined, and he tries to make Oliver hope he is never born. Leslie has almost 
all stations on TV, magazines, and newspapers throughout the United States, and this makes Leslie easier to revenge.

This ambitious woman aims to put others in the white house to replace Oliver, Leslie never stops before Oliver's career is destroyed, she wants Oliver to suffer the same as she feels.

\subsection{The Implication of the Protagonist's Attitude in the Novel}

Leslie Stewart is a woman plagued by revenge supported by his two dominant attitudes, selfish and ambitious. By his selfish and ambitious, she is willing to do anything to achieve his goals even if it harms himself. Stewart's selfish and ambitious is unique in its intensity, however this would be overlooking everything that occurs because of the two dominant negative attitude, one the most obvious being a loss and empathy and humanity. Leslie's did not care for the life of other people if it meant possibilities of achieving his revenge. She has turned himself into a selfishness and ambition monstrous woman.

She is ambitious woman, starts by courting a rich media mogul and soon is married to him. With his death he becomes the owner of his vast empire of newspapers and publications. She gets involved with running and expanding the empire, acquiring more newspapers and soon establishing herself as one of the largest publishing empires in the world. The statement was strengthened by quotations in the novel below:

LESLIE WILL YOU MARRY ME?...... Leslie opened eyes and looked up at Hanry. "yes, I want marry you” (Sheldon, 1997:61).

He had been a dear, sweet man, and she had used him because she wanted him to help her get revenge against Oliver (Sheldon, 1997:74).

She had been busily expanding her empire and had acquired a chain a newspapers and television and radio stations across the United States, as Well as in England, Australia, and Brazil (Sheldon, 1997:146-147).

And after getting it all she became a very selfish woman, she did not even care about the quality of her mass media. She just focused on cheap news about Oliver Russell.

\section{Conclusion}

The protagonist of the novel The Best Laid Plans written by American novelist, Sidney Sheldon, Leslie Stewart, is not only a selfishness person but he has a ambitious personality. She usually does anything for the purpose of being realized. She was even willing to spend the night with someone who was hated and devised the best laid plans possible plan to destroy his ex-fiancé. She has been corrupted by two dominant, selfish and ambitious negative attitudes and this makes reasonable communication difficult and arguments impossible to resolve fairly because she will not accept the viewpoint of others, no matter how much loss she incurs because she is right has his own desires without thinking about others. Nearly all his crew do not like or enjoy being with him, but Leslie Stewart does not notice this problem or cannot change his attitude because 
his personality enjoys being selfish and ambition much more than being liked by or having a respectful, loving, and accepting attitude toward other people.

Anyway, his selfish and ambitious can also be judged reasonable because she lives to revenge again evil reasoning nature and she is dumb and deaf to advice as she thinks she is superior to everyone else. She is always right while others are wrong. And finally his ambitious and selfish leads to an unpleasant ending.

\section{References}

Barsukova O. (2014). Professional ambition: ambition as a motive of professional and career development of person. JPMNT International Volume 2 Issue 2.Q. 95-98

Creswell, J. (2007). Qualitative Inquiry \& Research Design: Choosing Among Five Approaches, 2nd ed. California: Sage Publication.

Creswell, John W. (2009). Research Design: Qualitative, Quantitative, and Mixed Methods Approaches. Newbury Park: Sage Publications.

Crocker, J., Canevello, A., \& Brown, A. A. (2017). Social motivation: Costs and benefits of selfishness and otherishness. Annual Review of Psychology, 68,299325. Retrieved from http://dx.doi.org/10.1146/annurev-psych-010416-044145 on 29 June 2019.

Ernawati. (2012). A Study of the Protagonist's Negative Attitude in Herman Melville's "Novel Moby Dick". Medan: Universitas Islam Sumatera Utara (UISU).

Hayati. (2019). 4 Different Types of Attitudes of People As Per Psychology. Retrieved from https://stylesatlife.com/articles/types-of-attitudes/ on 25 June 2019.

Hidayati. (2019). Anguish in Alexander Dumas' Novel "The Count of Monte Cristo". Language Literacy: Journal of Linguistics, Literature and Language Teaching. Retrieved from https://jurnal.uisu.ac.id/index.php/languageliteracy/article/view/1994/pdf_1 on 15 May 2019.

Lopper, Wiliam. (1992). Human Attitude, New york: Macmillan Press.

Poniman. (2007). Pengaruh Sistem Informasi Akuntansi Manajemen Terhadap Kinerja Manajerial. Jurnal Persepsi Akuntansi.

Schiffman \& Kanuk. (2004). Perilaku Konsumen. Jakarta: Prentice Hall.

Serli, Eka. (2017). Struggle of Woman In The Nove Sing Me To Sleep By Angela Morrison (The Analysis of Feminism). Makassar: Universitas Islam Alauddin.

Wicker, A.W. (1969). Attitudes Versus Actions: The Relationship of Verbal and Overt Behavioral Responses to Attitude Object. Journal of Social Issues. 